Articles

\title{
Multimodal critical discourse analysis of the cinematic representation of women as social actors
} Análise crítica do discurso multimodal da representação cinematográfica de mulheres como atores sociais

Fábio Alexandre Silva Bezerra'

\begin{abstract}
In this paper, an expanded version of the visual social actor network (van Leeuwen 2008) is suggested in integration with the classification of fields proposed by Martin (1992). In the context of multimodal critical discourse analysis, such network has provided a template for the discussion of the data aiming to reveal and interrogate the construal of women's agency in the introductory part of the first film Sex and the City (2008). Overall results place women's actions mostly in the private sphere but also reveal instances of gender performativity (Butler 1990) that question social norms for women mainly imposed by the media.
\end{abstract}

Keywords: Visual social actor network; MCDA; women's agency; performativity.

1. Departamento de Letras Estrangeiras Modernas e Programa de Pós-Graduação em Linguística da Universidade Federal da Paraíba. João Pessoa, Paraíba - Brasil. https:// orcid.org/0000-0002-3383-0188. E-mail: fabes10@yahoo.com.br. 


\section{RESUMO}

Neste artigo, uma versão expandida da rede visual de atores sociais (van Leeuwen, 2008) é sugerida em integração com a classificação de campos proposta por Martin (1992). No contexto da análise crítica do discurso multimodal, essa rede sistêmica forneceu um modelo para a discussão dos dados com o objetivo de revelar e interrogar a construção da agência de mulheres na parte introdutória do primeiro filme Sex and the City (2008). Resultados gerais localizam as ações das mulheres principalmente na esfera privada, mas também revelam instâncias de performatividade de gênero (Butler 1990) que questionam normas sociais para as mulheres principalmente impostas pela mídia.

Palavras-chave: Rede visual de atores sociais; ACDM; agência das mulheres; performatividade.

Life on screen dwarfs and strips of its charm the life lived: it is the lived life which seems unreal, and will go on looking and feeling unreal as long as it is not refashioned in its own turn into screenable images.

(Bauman 2000:84)

\section{Introduction}

In this epigraph, addressing the impact the media have on people's individual and collective imagination, Bauman (2000) draws our attention to possible differences between life on screen and life lived, i.e. between what is represented in telecinematic texts and what is experienced in everyday life. The author seems to allude to diacritic elements in telecinematic discourse (Piazza, Bednarek and Rossi 2011) used as resources to create specific representations of reality, which might, in turn, seem more appealing and/or easier to absorb than the real lived experiences of viewers. In this sense, these semiotic resources are "deeply political" (Bouvier 2018:205).

Such claim underlines the imbalance oftentimes created by the media in people's perception of reality and of its socioeconomic consequences in contemporary society, as today's world becomes increasingly more saturated by consumerism and the pursuit of 
identities projecting what seems to be valued socially and culturally (Bauman 2000). In this context, this paper aims to discuss visual representations of women as social actors ${ }^{2}$ in the first film Sex and the City ${ }^{3}$ (2008) - SATC, thus foregrounding the extant bidirectional relationship between identities and discourse.

The TV series has received considerable attention both in the media (blogs and news outlets) and in academia ${ }^{4}$, in areas such as feminist, media, film and cultural studies. Among these, while Di Mattia (2004) problematizes the search for Mr Right by questioning the idealized male partner as an unreachable model, Montemurro (2004) highlights how the TV series duly depicts the challenging balance between motherhood and work. In the area of language/discourse studies, Bezerra (2008) carries out a critical discourse analysis of gender representation in the discourse of the narrator while Bubel (2011) addresses how friendships are forged.

The results presented in the present paper have been obtained by means of a meaningful, productive and timely blend between studies in multimodality and in critical discourse analysis (CDA) - thus representing a contribution to research developments in multimodal critical discourse analysis (MCDA), a field of inquiry still in its infancy (Djonov and Zhao 2014; Ledin and Machin 2018). Emphasizing issues of language use, power and inequitable relations construed in

2. Aligned with propositions in van Leeuwen (2008), the term 'social actor' is used here to indicate that the analytical emphasis surpasses the linguistic identification of categories of participants involved in the events described to include a sociological aspect of the implications of the modelling construal one builds about/of individuals in (multimodal) texts. Besides, the term 'agency' is recurrently used in this paper to refer to the extent to which social actors may act independently while also being impacted by social, cultural and political structures. Rather than synonymous, these terms should be seen as complementary when observing sociological implications of visual/linguistic representations of individuals in society.

3. This film presents a continuation of the stories in the lives of the four main characters - Carrie, Miranda, Charlotte and Samantha - since the homonymous TV series ended in 2004 after a total of six seasons.

4. Upon search on Portal de Periódicos CAPES/MEC, no papers were found to have investigated the film Sex and the City since its release in 2008. The search criteria were: sex and the city; film; last 10 years; any language; peer-reviewed journals. Whenever 'Sex and the City' was mentioned in the papers found, it was either about the TV series or only mentioning the film (among others) as an instance of the theme being discussed, i.e. it did not make up the data being analyzed. Last access on May $5^{\text {th }}, 2019$. 
and through discourse by a combination of modes in a wide range of contexts, MCDA nonetheless offers a useful template for the discussion of gender-related issues in contemporary society by investigating how multiple semiotic modes create more subtle representations of gender inequity, especially those in popular culture media, such as TV, film and magazines.

In this respect, Ledin and Machin (2018:60) highlight the need for "clear, robust concepts [in multimodality] that can be used as part of CDA with its emphasis on digging out the discourses buried in texts to reveal (...) power relations and ideologies", thus strengthening the connection between these two fields of inquiry. MCDA, as an interdisciplinary approach, attempts to pull research out of its disciplinary silos, incorporating contributions of different fields for a more robust understanding of how multiple semiotic modes (verbal, visual, haptic, auditory, etc.) interact textually and discursively.

Importantly, besides revealing possibly biased representations and contesting oppressive social relations, the critic also needs "to take up the fair position (...) to not only negate but to add" (Roderick 2016:164). In other words, research in MCDA also needs to question the reasons for such imbalances, as an attempt to start de-naturalizing beliefs that sustain unequal relations of power in society.

Although numerous studies have addressed the ways in which still images construe representations of reality in systemic-functional and/or socio-semiotic terms (Bezerra, Nascimento and Heberle 2010; Bouvier 2018; Chen and Machin 2014; Kerry 2016; among many others), there is considerably more to be achieved in terms of theoretical and methodological consistency as far as dynamic ${ }^{5}$ images are concerned. Aiming to add to important contributions worldwide (Bateman 2009; Bezerra 2012, 2016; Böhlke 2008; Iedema 2001; Lima-Lopes 2016; O'Halloran 2004; Tseng 2009; van Leeuwen 1996), this paper, adopting a combined systemic-functional (Halliday and Matthiessen, 2004; Martin 1992) and socio-semiotic approach (van Leeuwen 2008), proposes to reveal how the representations of women in the film SATC

5. Dynamic multimodal texts are "film and video texts which display different and constantly varying configurations of sound, image, gesture, text and language as the text unfolds in time" (O’Halloran 2004:110). 
either expand or limit the domains of action in which they can operate. From Halliday and Matthiessen (2004), the notion of system networks is explored; from Martin (1992), part of the provisional classification of fields is used; and from van Leeuwen (2008), the visual social actor network is expanded, thus offering a broader foundation for the discussion of women's agency in this filmic production.

\section{A methodological account}

The results discussed are part of a wider investigation in the field of MCDA (Bezerra 2012), having been updated considering studies in the area published in major national and international journals in the past six years. While this paper emphasizes the visual elements, my unpublished doctoral research (Bezerra 2012) provides a more encompassing verbal, visual and intermodal analysis of SATC. Additionally, due to constraints of space, only the introductory part (3'50") of the film (Intro) is analyzed here in order to demonstrate and discuss the expanded visual social actor network proposed.

In the Intro, the audience is given a summary of the most important moments in the four main characters' lives throughout the originating homonymous TV series, thus allowing for fans to be reacquainted with the characters and for newcomers to have some background information before seeing the new events in the film unfold.

In the broader investigation (Bezerra 2012), a number of steps had to be taken to obtain the data presented and discussed in the analysis section about the visual representation of women as social actors. First, both the verbal and visual texts were broken down into the smallest units of analysis (clauses and shots, respectively), which also allowed for the intermodal analysis to be carried out. The representational resources mobilized in the multimodal text were analyzed in systemic functional terms (Halliday and Matthiessen 2004), where the ideational content is described as processes, with attending participants in specific circumstances.

These processes could be realized as action, perception, cognition, emotion, desideration and saying. The participants involved in such processes in specific contexts could be either dynamic or passive. 
The fact that the dynamic image, like the verbal text, can also realize processes of emotion and desideration is also proposed. In other words, unlike the still images (Kress and van Leeuwen 2006), the dynamic text presents a greater ideational meaning potential - much in the same terms as verbal language. Having explained that, let us focus on how this specific set of data was formulated as only images are addressed in this paper.

Using software for video editing (ELAN and FastStone Player), a detailed layout of the dynamic image in tables was presented, and all actions which women carried out could be informed. In the analysis section ahead, based on Table 2, only the actions with significance in regard to gender identity are listed and discussed. For a more thorough description of the steps in the analysis of the dynamic image, see Bezerra (2012), where the text was separated into comprehensive units proposed by Baldry and Thibault (2005) to be able to identify and classify the data accordingly: whole text $>$ macro-phase $>$ phase $>$ sub-phase $>$ shots $>$ visual transitivity frames.

Following all these levels of analysis for the dynamic image, it was possible to locate and quantify the actions in which women were involved, thus allowing for a discussion of the complexity and extent of their agency by utilizing the expanded visual social actor network presented and explained in the next section.

\section{Some theoretical underpinnings}

In order to reveal and discuss the visual representations of women in SATC, emphasis has been placed on how they have been portrayed as social actors and the implications of such construal for women's agency in contemporary society, especially considering that identities are often produced through articulations with popular culture. In that respect, the theoretical underpinnings that guide the concept of gender in the present study are delineated next.

Generally speaking, there are two opposing ways to view and explore identity (Benwell and Stokoe 2006): the essentialist and the constructivist perspectives. On the one hand, (gender) identity can be understood as something essential, pre-discursive and, therefore, 
stable - rendering it as something that one possesses. On the other hand, identity is seen as constructed, discursive and, therefore, unstable meaning something that one performs.

In line with the discursive view of identity, informing the present study, Butler $(1990,2004)$ describes gender as performativity. This concept purveys the notion that gender is something that one does, something that is actualized in the everyday acts of performativity, entailing a reiterative practice (Roderick 2016), rather than a pre-given construct. A number of studies have addressed how performativity is construed by tackling social issues like weight loss (Mishra 2017) and masculinities (Kerry 2016; Pimenta and Natividade 2012), among others.

Understanding gender as performativity contributes to dessentializing notions of identity, avoiding generalizing interpretations of individual and collective experiences. In other words, women's social agency should be understood as malleable, which does not mean believing in the chimera of unrestrained freedom to experience and perform identity in all contexts, as individuals and different social groups are mobilized by the social structures under which we all operate. A multimodal critical discourse investigation of gender representation ought, therefore, to address how images construe identity by deploying the semiotic potential available to meet particular discursive goals in specific contexts.

The relevance of the focus on the meaning potential of the image has been recently stressed by some scholars arguing for a socially and affordance-driven approach to MCDA (Machin 2016; Machin, CaldasCoulthard and Milani 2016). Such approach is informed by the work of Halliday (1978) and Halliday and Matthiessen (2004) in systemic functional theory (SFL), emphasizing "not the idea of a formal, strict grammar but one of a system of semantic choices and networks" (Machin, Caldas-Coulthard and Milani 2016:302).

Although an important aspect of an affordance-led approach to MCDA is to describe and discuss the meaning potential of the specific semiotic resources under analysis (see Bezerra 2012), the core aims of this paper, as previously indicated, are to describe and expand a visual social actor network as well as to discuss and problematize the construal of women's agency in SATC. 
In the first heuristic explorations of the data using the network proposed by van Leeuwen (2008), it became apparent that more needed to be said about the representations found in the analysis than the system network available seemed to offer as described options of meaning. Importantly, this expansion is surely not intended as criticism towards the originating network (van Leeuwen 2008); conversely, its aim is simply to highlight to the analyst the more in-depth analysis that may be carried out by moving rightwards in the system previously described as additional levels of delicacy were proposed.

This path (from data to system network) allowed for an interpretation of the results that was not simply limited to the network proposed and its terminology, thus avoiding the case that "examples are chosen that allow concepts and models to be illustrated" (Machin 2016:326, citing Forceville 1999). Instead, the system network was expanded so as to account for the aims of the present study, based on the premise that "the actions and agency of represented actors can be analysed by attending to exactly what types of activities they perform" (Roderick 2016:397).

Since the main concern here is to address visual representations of women in SATC in regard to their spaces for action and the impact they might have on other people or things, van Leeuwen's (2008) visual social network (Fig. 1) proves useful in describing the goings-on in the dynamic image in terms of what women are (not) represented to do and with whom they interact when doing these things.

Figure 1 - Visual social actor network.

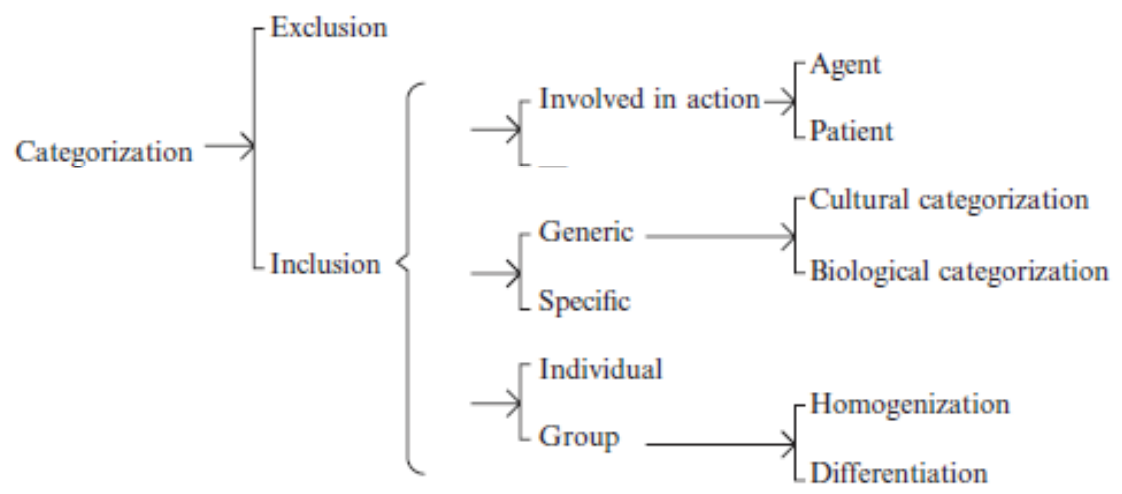


In this system network, van Leeuwen describes options of meaning when considering the potential available for representing social action. First, individuals may be either included or excluded from the visual text. If included, there are three additional sub-sets of possible meanings considering their involvement in actions as agents or patients, their categorizations and their placement as individuals or groups. For the purpose of this paper, only the sub-set of involvement in action is considered, which is where the expansions proposed appear.

The first expansion consists in the addition of considerations about the fields of discourse in which the actions involving agents and patients are located. In other words, aiming to address women's social agency in SATC, it did not suffice to simply describe the actions with which they are involved; equally important was to classify these actions according to the contexts in which they are found. For that, the classification of fields proposed by Martin (1992) was partly integrated with van Leeuwen's (2008) visual social actor network. Before explaining how this integration occurs, a brief description of Martin's system network below is provided.

Discussing field agnation, more specifically the nature of socialization in such fields of discourse, Martin (1992:544) first describes two main entry points into the system (Fig. 2): 'oral transmission' and

Figure 2 - Provisional classification of fields.

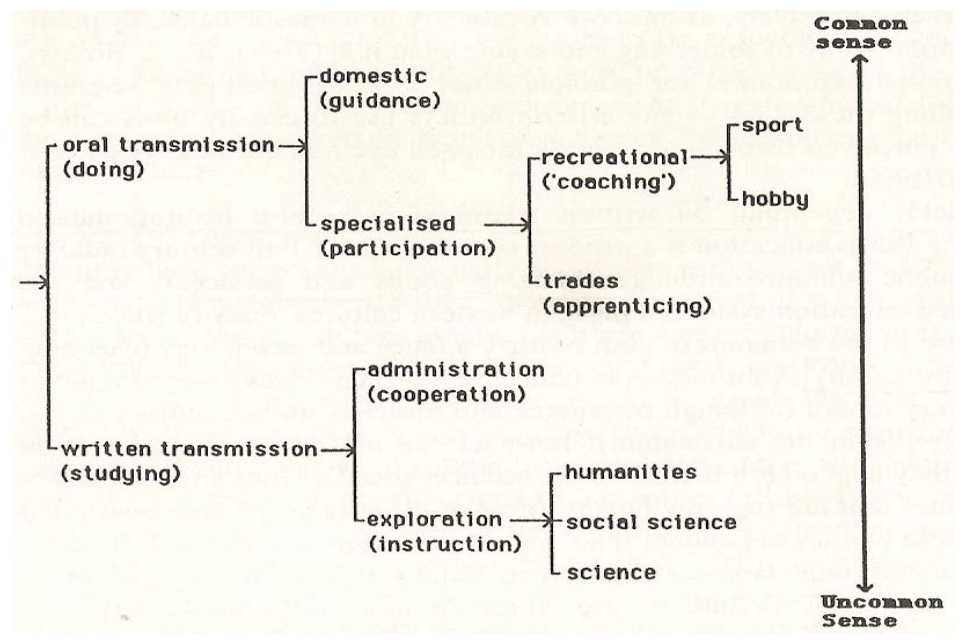


'written transmission'. In all the data analyzed, only one case of 'written transmission' was found, when the character Miranda is represented reading and signing a contract to become a partner in the law firm where she works. For this reason, only the feature of 'oral transmission' was considered in the analysis presented in this paper.

Looking at the system 'oral transmission', the feature 'domestic' (renamed here as 'non-specialized') is in contrast with the specialized fields of discourse. In these, one may be involved in recreational or trade events, with the former being further divided into activities related to sports and hobbies. As the primary focus in this paper is to state if women's actions are placed in the specialized or non-specialized field, the further sub-features of specialization were not considered.

In regard to the accuracy of such classification of fields, Martin (1992:546) cautions against "the danger that the more domestic fields be misinterpreted as natural theories of experience with the more technical ones treated as semiotic construals of reality". In an effort to avoid statements that might place either women or men in pre-established roles pertaining to conceptions of what is perceived to be natural or cultural, such claim is rather significant considering that "all fields are semiotically constructed" (Martin 1992:546).

Besides adding the features 'specialized' and 'non-specialized' in the sub-system of 'inclusion' (van Leeuwen 2008), the expansion proposed here also adds more levels of delicacy to the sub-feature of 'agent'. For the final expanded system network, see Figure 3 below. 
Figure 3 - Expanded visual social actor network.

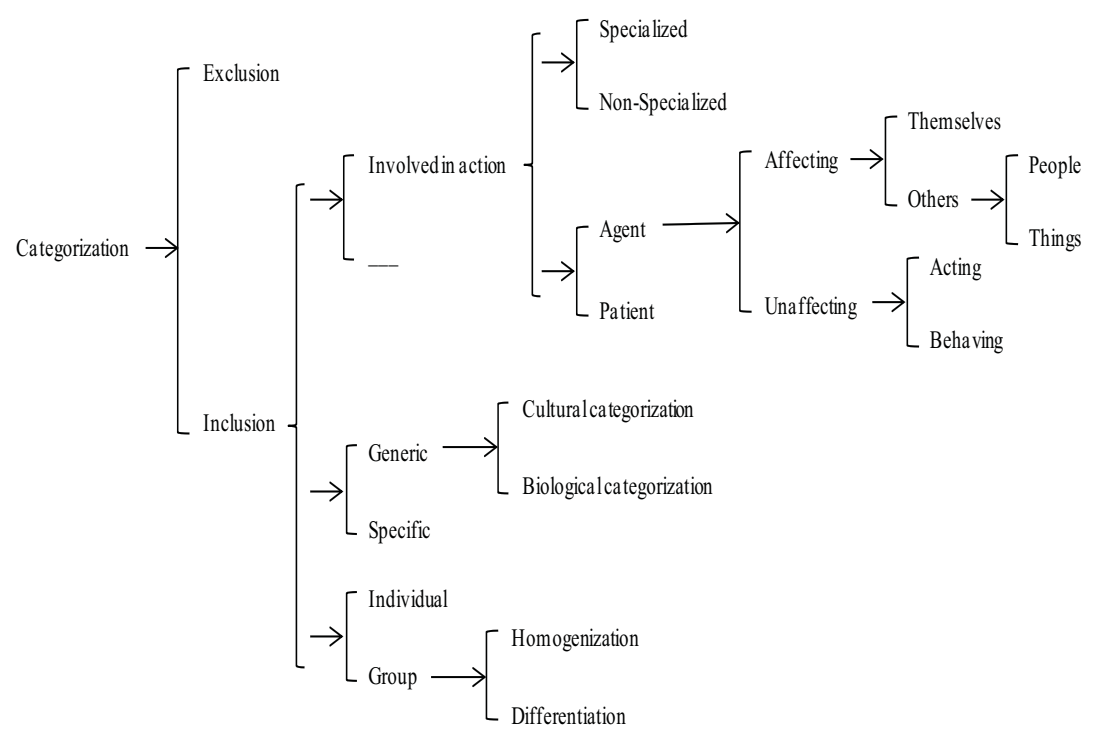

Source: Bezerra (2012:254), adapted from van Leeuwen (2008) and Martin (1992).

First, notice that the agent may or may not affect someone or something. If affecting, they might affect either themselves or others. If affecting others, these may be either people or things. Now, if not affecting anyone or anything, the agent may only be acting (e.g. walking) or behaving (e.g. laughing). These additional levels of delicacy arguably allow for a more in-depth look into the types of actions and their reach, which is rather useful when discussing the complexity and extent of women's agency in the film under analysis.

In the following section, this system network, more specifically the feature 'involved in action' along with its sub-features and corresponding levels of delicacy, is explored in the analysis of the data collected from the Intro of the film, aiming to reveal and hopefully contribute to de-naturalizing the ways in which women's agency have been portrayed, which arguably informs how they are perceived by society at large. 


\section{The visual representation of women as social actors}

Having outlined the expansion proposed to van Leeuwen's (2008) visual social actor network, and stressed the focus on the discussion of gender issues as far as women's agency is concerned, next is description and discussion of the data found in the Intro of the film regarding the dynamic image only.

When discussing how participants are represented visually, one first needs to consider what has been included in and excluded from the multimodal text (Fig. 3). First, the discussion emphasizes who has been excluded from the depictions precisely because it "is always a symbolic form of social exclusion, not acknowledging the existence of certain people or kinds of people who live and work among us" (van Leeuwen 2008:142). Roderick (2016:396) also adds that, besides "analysing how actors are represented, it is equally important to consider those meaningful absences which equally underwrite the homogeneity/ solidarity being produced through categorisation" in the visual text.

The first noticeable absence from the representations in the Intro is that of black people - not being displayed even in the background, much less interacting with any of the four main characters. Highlighting this exclusion is important especially because the introductory part of the film, as previously explained, presents a summary of the most relevant events and character relations in the TV series, thus revealing that both the TV series and the film are almost entirely about white people living in New York (Manhattan and Brooklyn). This fact revealed from data analysis is especially relevant as "gender imbalances never operate alone but intersect with other axes of inequality" (Machin, CaldasCoulthard and Milani 2016:306), such as class, age, sexual orientation and ethnicity.

Before further analysis of the Intro, the character Louise, Carrie's personal assistant in the film, needs to be mentioned, as her role, though minor, is not at all insignificant. However, she only appears later in the storyline. Since this paper focuses on the film Intro due to its relevance, the fact that no black person is displayed in any of the frames is in itself revealing of a lack of racial/ethnical diversity. 
Other important markers of difference almost entirely absent from the depictions are those of older age and heavier body size. In general, depicted individuals are young, slim, white, apparently middle class, straight women and men. Although this is a significant result, the character Harry (Charlotte's second husband), though appearing rather briefly in the visual text, is an important representation of diverse body size and image. Having fallen in love with Harry, Charlotte even converted to Judaism, his faith - which, opportunely, is also duly represented in the dynamic image analyzed, thus reflecting an instance of attention to religious diversity.

Such lack of representativity seems markedly less realistic knowing all events occur in New York - one of the most diverse cities the world over in numerous aspects. Statistically speaking, for instance, the Organisation for Economic Co-operation and Development (OECD 2017 ) reports that $38.2 \%$ of the adult population in the US is obese, of which women's percentage is a little over that of men ( $41 \%$ women, $35.5 \%$ men). This is why a multimodal analysis of gender identities needs "to think about the way that people in representations are placed in the social world, which parts of their identity are foregrounded, backgrounded or hidden" (Chen and Machin 2014:290).

Regarding sexual orientation, no identifiable gay/lesbian/bisexual characters are displayed in the Intro, with the exception of two male extras who kiss in the background (much to Samantha's disappointment). There are, nevertheless, two gay men who appear later in the film, and who also were characters in the TV series: Stanford and Anthony Carrie's and Charlotte's best male friends, respectively. Precisely for being best friends with two of the main characters, their absence in the Intro cannot be overlooked - leaving the audience to wonder why they are not placed more centrally in the film as well.

Although these are not the only absences in the visual construal of the Intro in this film, underlining ethnicity, age, class, sexual orientation and body size seems sufficient to clarify who is primarily depicted as viable images in the telecinematic text under analysis. Next, considering the choices of inclusion in the data analyzed, results might contribute to understanding the constraints and the potential of the dynamic image for more equitable (gender) representations. 
In order to understand the annotations in Table 2, see below the abbreviations of the names of the film characters appearing in the shots analyzed in the Intro (Table 1). For instance, when referring to the visual occurrences of women getting married in the Intro, Table 2 shows "getting married [TR, HR, ST]", which indicates the two instances where Charlotte gets married, first to Tray (TR) and later to Harry (HR) - and then the portrayal of Miranda getting married to Steve (ST). In other words, the abbreviations in Table 1 show the people or things that are the recipients of women's actions.

These are not, however, the only people depicted in the dynamic image. Other individuals also form the background against which the protagonists and their co-stars interact. Some of those extras are at times mentioned whenever their visual construal is noticeable enough to allow for analytical work as far as gender issues are concerned, being referred to in general terms as woman (W1 and W2) or man (M1) - the numbers indicating the order in which they appear on the screen.

Table 1 - List of abbreviations of character names involved in the shots analyzed.

\begin{tabular}{|l|l|l|l|}
\hline C - Carrie & CH - Charlotte & MR - Miranda & SM - Samantha \\
\hline TR - Trey & HR - Harry & RS - Rose & LL - Lily \\
\hline ST - Steve & BR - Brady & SH - Smith & MB - Mr. Big \\
\hline
\end{tabular}

Table 2 - Summary of women's visual social agency in the shots analyzed (Intro).

\begin{tabular}{|c|c|c|c|c|c|}
\hline \multirow{6}{*}{$\begin{array}{l}\mathbf{A} \\
\mathbf{G} \\
\mathbf{E} \\
\mathbf{N} \\
\mathbf{C} \\
\mathbf{Y}\end{array}$} & \multirow{5}{*}{$\begin{array}{l}\mathrm{A} \\
\mathrm{G} \\
\mathrm{E} \\
\mathrm{N} \\
\mathrm{T}\end{array}$} & \multirow{3}{*}{ Affecting } & $\begin{array}{l}\text { Them- } \\
\text { selves }\end{array}$ & & \\
\hline & & & \multirow[b]{2}{*}{ Others } & People & $\begin{array}{l}\text { getting married }[\mathrm{TR}, \mathrm{HR}, \mathrm{ST}](3), \text { hugging }[\mathrm{MB} \text {, } \\
\mathrm{SH}](2), \text { having sex }[\mathrm{men}](7), \text { kissing }[\mathrm{ST}, \mathrm{MB}] \\
(6), \text { holding }[\mathrm{BR}, \mathrm{MB}, \mathrm{RS}](6)\end{array}$ \\
\hline & & & & Things & $\begin{array}{l}\text { drinking [?] (3), putting on [make-up, } \\
\text { sunglasses] (2), eating [?] (3), holding [books, } \\
\text { photo frame, photo] (3) }\end{array}$ \\
\hline & & \multirow{2}{*}{$\begin{array}{l}\text { Unaffect- } \\
\text { ing }\end{array}$} & Acting & \multicolumn{2}{|c|}{$\begin{array}{l}\text { lying down (3), screaming (3), standing (7), walking (18), } \\
\text { running (2), working (6) }\end{array}$} \\
\hline & & & $\begin{array}{l}\text { Behav- } \\
\text { ing }\end{array}$ & \multicolumn{2}{|c|}{ smiling (24) } \\
\hline & \multicolumn{2}{|c|}{ PATIENT } & \multicolumn{3}{|c|}{ hugging [W2, CH, MR, SM, C] (5), holding [RS] (1) } \\
\hline
\end{tabular}


The first more general observation is the absence of actions in which women affect themselves, underscoring the focus of their agency on either other people or things (affecting), as well as on actions which are intransitive (unaffecting). This result indicates the decision in the Intro to present the four main characters by emphasizing their actions and the people with whom they interacted throughout the TV series.

The second more general observation is that there are more instances of women's social agency not affecting anyone or anything. They are depicted visually 63 times either acting (39) or behaving (24) as opposed to 35 instances affecting either people (24) or things (11). This fact seems to indicate that women are mostly construed to be perceived as individuals, focusing on their personal characteristics. Such decision is arguably aligned with the main objective of the Intro to (re)introduce the main characters to viewers.

Importantly, all 24 instances of women affecting other people are limited to their personal relationships, which possibly circumscribes performativity to the private sphere. As Butler (1990) argues, (gender) identity is actualized in specific quotidian actions, part of reiterative practices creating the general idea of how individuals are to be perceived. In this case, the construal seems to position women in places where their interactions only seem valid in private, more personal situations - a disquieting notion, considering the real pervasive impact of women in today's contemporary society in a wide range of contexts and domains.

Besides being restricted to the characters' private lives, the 24 occurrences of women's actions affecting other people are circumscribed to five rather specific actions: getting married, hugging, having sex, kissing and holding - arguably implying that these actions constitute the more substantial aspects of their lives. Even taking only their private lives into account, such a constraining range for women's actions needs to be questioned and rejected for being utterly unrealistic and problematic.

Another striking result in terms of (gender) identity representation is the portrayal of Samantha, in another montage, having sex with 
seven different men on different occasions (Fig. 4) ${ }^{6}$. With sex being a pivotal element of both the TV series and the film, why not include instances of the other characters having sex, thus creating a more truthful construal of the events in the TV series? Although Samantha is fittingly acknowledged for her free-thinking ideas and practice of sex, having all 7 instances focusing solely on her does not seem to be justifiable. Having said that, one must also remember that only a very small cohort of women over forty years old are represented as sexually active in telecinematic discourse (Piazza, Bednarek and Rossi 2011), making Samantha a meaningful example in that sense.

Additionally, no other character (female or male) is depicted interacting with people other than their friends and family, except for one situation in which all four main characters (C, CH, MR and SM) smile at an attractive young man passing by only to find out he is gay as he kisses another man waiting for him in the background (Fig. 5). Seemingly innocuous, this result seems to place most of women's agency in their private/social spheres in interaction with only other familiar men/women.

Figure 4 - Samantha having sex.

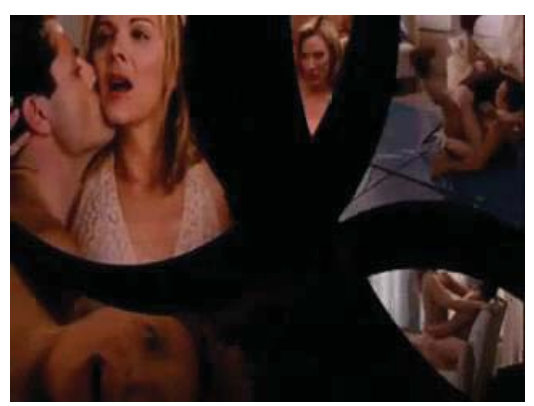

Source: SATC (HBO).
Figure 5 - Leading characters smiling.

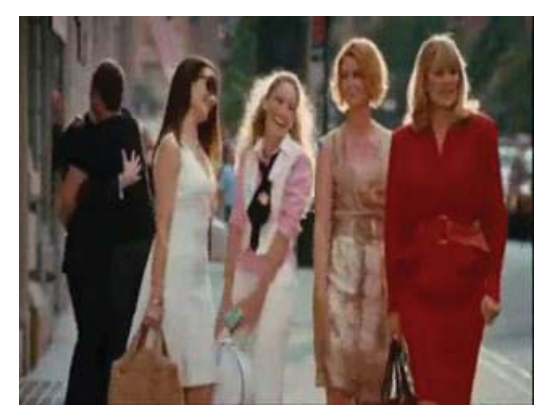

Source: SATC (HBO).

6. Common practice in the publishing sector, a limited portion of copyrighted material may be used when constituting fair use. According to Section 107 of the U.S. Copyright Act, "the fair use of a copyrighted work, including such use by reproduction in copies or phonorecords or by any other means specified by that section, for purposes such as criticism, comment, news reporting, teaching (including multiple copies for classroom use), scholarship, or research, is not an infringement of copyright" (USCO 2016:19). Nevertheless, full attribution must be given to $\mathrm{HBO}$ - Home Box Office, Inc. as the copyright holder of the motion picture from which the still images in Figures 4-13 were extracted for use in this paper. 
Emphasizing the instances of performativity of motherhood, there are depictions of Charlotte (Fig. 6) and of Miranda (Fig. 7) holding their children, creating the image of dedicated caretakers, both in their family leisure time accompanied by their husbands (Harry and Steve, respectively). Unsurprisingly, the focus on Charlotte's motherhood is present throughout different shots, since this is a rather important aspect in her life having been unable to conceive, leading her and her husband to adopt Rose.

However, having chosen her career over early motherhood, Miranda had a significantly different experience as she got pregnant unexpectedly, marrying Steve sooner than planned. The scene of their wedding ceremony is where one of the two instances of kissing in the Intro appears, when bride and groom finally kiss.

The other instance occurs when Carrie kisses Mr. Big (Fig. 8) in front of his apartment building. Considering that a substantial part of the stories shared by the four main characters in the TV series was about their personal (sexual) relationships with other men, the Intro surprisingly emphasizes only Miranda's and Charlotte's latest relationships - showing their husbands and children, while creating a better summary of events for Carrie (previous boyfriends) and Samantha (previous sexual partners).

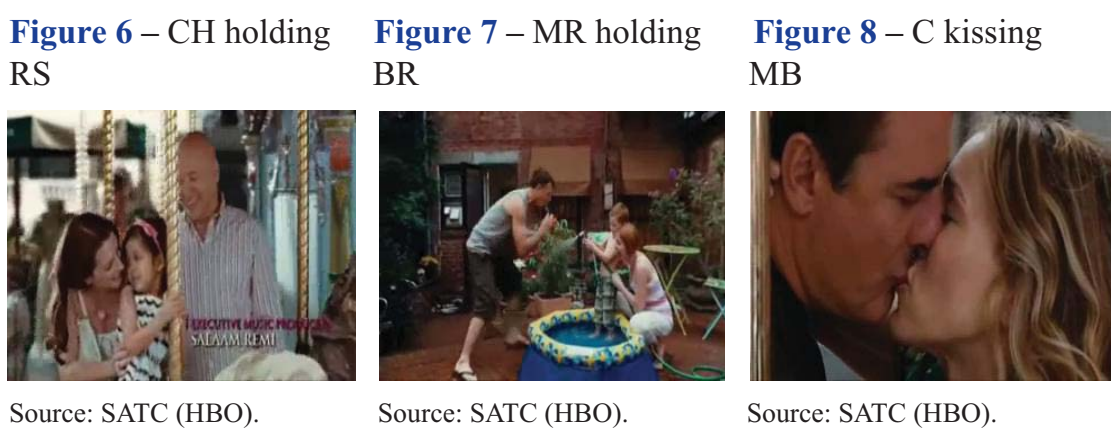

Looking at the instances where women acted onto things, most of them are related to their social range of action (drinking, putting on make-up/sunglasses, eating), when the main characters are depicted in restaurants/bars having a meal and drinking with each other, construing 
the concept of close-knit friendships. The other 3 instances show Carrie holding and looking at a photo of herself and her three best friends, and holding the books she wrote, portraying an action with a broader social scope. However, instead of showing Carrie at a bookstore, for instance, where her books would be in display, the depiction was simply of her holding the books in her bedroom. This way, an action with a more public relevance still finds itself somewhat confined to a private domain.

Now, regarding occurrences of women's agency not affecting anyone/anything, they describe two types of events: women are either acting (39) or behaving (24). When acting, they are mostly depicted either walking (18) or standing (7), with other actions happening less frequently: working (6), lying down (3), screaming (3) and running (2). The data results show women mostly walking around the city, which helps create the context in which their lives unfold: New York - one of the most recognizable, ethnically diverse and densely populated cities in the world.

Walking around the city, these women also highlight other elements of life in the Big Apple that have been an integral part of SATC: commerce, fashion and relationships. For example, in the opening frames of the Intro, there is a young woman (W1) depicted standing in front of a shop window and smiling at a mannequin (Fig. 9), revealing her interest in what is for sale, confirmed by the accompanying narration: Year after year, twenty-something women come to New York City in search of the two L's: labels and love. The role of fashion in SATC is mostly defined by wearing designer clothes and shoes, privileging a desirable image contradictorily unattainable for most women.

In addition, Carrie is represented walking and smiling (Fig. 10) as she passes by a group of young girls resembling herself and her best friends. In this shot, Carrie is wearing a white gold flower cocktail dress, aiming to set her apart as the fashion-forward leading character. 
Figure $9-$ W1 at shop window.

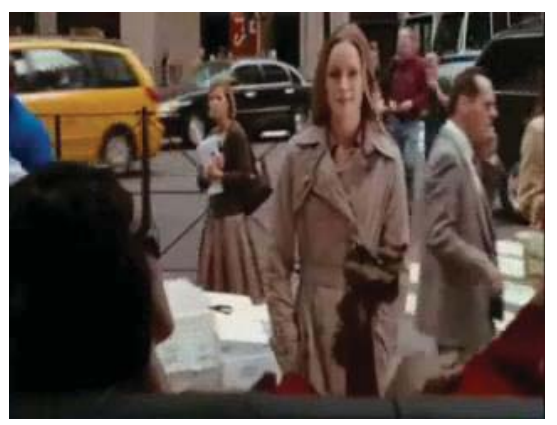

Source: SATC (HBO).
Figure 10 - Carrie walking/smiling.

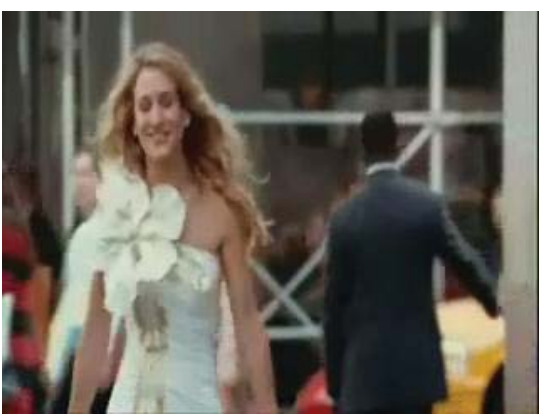

Source: SATC (HBO).

Relationships are another key element in the visual construals of SATC, whether referring to physical ones (Fig. 4), to friendships (Fig. 5) or to romance (Fig. 6, 7 and 8). Even though different types of relationships are depicted, it appears that women are acknowledged as sexual beings only privately, except for Samantha, the overtly more sexual character, who is more often than not criticized for an allegedly lack of moral probity. Such constraining depictions in the media need to be questioned, as they seem to legitimate narrow perceptions of gender, limiting them to roles and behaviors, when it needs to be understood as a complex web of factors that intersect in one's identity.

The most frequent occurrence of women's actions not affecting people or things is that of working (6), showing the main characters (except for Charlotte) involved in actions with a more public scope. However, out of these instances, only one actually happens outside of their home, when Miranda (a lawyer) can be seen in her office (Fig. 11). Another instance shows Samantha (a PR executive) working from home (WFH) while bathing in the sun in her bathing suit (Fig. 12) alongside her boyfriend (and client) Smith.

In the other four instances, Carrie is using a computer to write for her newspaper column from home as well (Fig. 13). Her work has been construed visually by means of a montage, where four different shots (at different points in time) are placed together in the same sequence of frames. This representation seems to purvey the idea that being a professional writer is a significant aspect in Carrie's life, thus creating the reiterative factor in the performativity of her (gender) identity. 


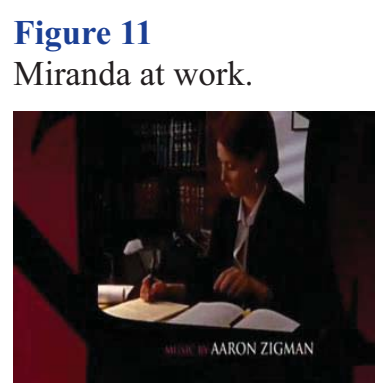

Source: SATC (HBO).
Figure 12

Samantha WFH.

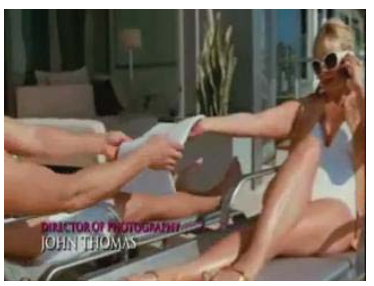

Source: SATC (HBO).
Figure 13

Carrie WFH.

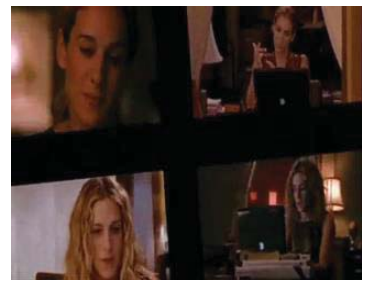

Source: SATC (HBO).

Although such result could be at first interpreted negatively as women are not seen occupying the office workspace, both Samantha and Carrie are self-employed, allowing them to decide their place of work. Additionally, this greater presence of women working from home seems consistent with a recent study by the United States Department of Labor (USDL 2016) showing that more women (23.5\%) work from home than men $(21.5 \%)$ in the USA, yet not necessarily receiving remuneration commensurate with their male work counterparts.

Quite oddly, in all instances of behavior depicted, women are simply smiling (24), which arguably helps to sustain an enduring connection between women and emotions (Galasinksi 2004). Such imbalances need to be examined as "hegemony relies on our perception that the dominant messages are just the way things are" (Kerry 2016:232).

At last, Table 2 shows all five female characters depicted $(\mathrm{CH}$, MR, SM, C and RS) and one extra (W2) as patients in only two types of actions: the acts of hugging (4) and holding (2). In all occurrences in which women are being hugged, the agentive position is occupied by men with whom the women are romantically involved: M1/W2, $\mathrm{HR} / \mathrm{CH}, \mathrm{ST} / \mathrm{MR}, \mathrm{SH} / \mathrm{SM}$ and MB/C. This result seems to confirm the choice to construe only heteronormative relationships in the Intro, even though gay, lesbian and bisexual relationships did exist in the TV series. For instance, Samantha dated Maria (played by Brazilian actress Sônia Braga) in the fourth season in 2001.

Whereas such representations seem to constrain ideas and images about romantic relationships in contemporary society as far as sexual diversity is concerned, the stable relationships of two of the four main 
characters seem to diverge from the social norm in relevant ways: both Miranda and Samantha date younger men who are less educated and rather less financially stable.

Miranda eventually marries Steve, while Samantha and Smith decide to live together in Los Angeles, where he could pursue his acting and modeling career more successfully. With their partners' support, both Steve and Smith end up finding a successful career path, underlining the positive impact their wives had in their lives in opposition to other frequent media representations of women's relationships where they are oftentimes markedly more pliant to the desires and needs of their male partners, especially when financially dependent.

In the expanded visual social actor network (Fig. 3), besides analyzing women's involvement in actions either as agents or patients, one must also consider in which field of discourse their actions are mostly located. In that respect, another salient result is that only one type of action has to do with the specialized field: that of working in its six occurrences, as previously described. All other instances are situated within the non-specialized field (Martin 1992), more specifically that of personal and romantic relationships, thus revealing the construal of a limited scope for women's agency.

Unlike what is depicted in the Intro, our lived everyday experiences confirm that women occupy varied areas of social life, impacting significantly on different groups and individuals. Such observation is pertinent considering that "the visual is particularly important in global communication since it can claim authenticity and resemblance, rather than being simply opinion" (Bouvier 2018:194), thus stressing the importance of critiquing media representations in order to interrogate the extent of their reliability. As (gender) identity is construed by means of performativity of reiterative actions in our daily experiences (Butler 1990), these representations of women in limited areas of life need to be called into question.

Even though the network proposed as analytical tool in this paper (Fig. 3) offers the critic a template from which to draw conclusions and critique imbalanced power relations and biased representations, it is not meant as an exhaustive description of possible meanings regarding 
social agency. Much like Sunderland and McGlashan (2013:492), we hope to have been able to demonstrate that meanings are "always contingent, co-constructed, interpretive, and cannot simply be read off from the [dynamic images] via the frameworks" proposed for analytical purposes.

Having described and discussed the construal of women's agency in the Intro of the film SATC, drawing data from the dynamic images by applying the expanded visual social actor network (Fig. 3), the next section presents a summary of the main findings as far as (gender) identity is concerned. Additionally, the relevance of conceptual and methodological proposals in MCDA is underlined for a broad spectrum of multidisciplinary studies, also stressing its significance for pedagogical purposes.

\section{Concluding remarks}

The main objectives of this paper were twofold: 1) to introduce and use the expanded visual social actor network (Fig. 3), and 2) to reveal and discuss the construal of women's agency in the Intro of the film insofar as the performativity of (gender) identities was concerned. The study was conducted within an MCDA approach in order to address how multiple semiotic modes can construe depictions that are oftentimes pervaded by inequitable power relations, setting forth biased gender representations in the media. Equally, attention must be paid to the constructive and emancipating power of discourse concerning its capabilities in creating more evenhanded social relations and identity portrayals.

Identity is a performative endeavor constituted in the discursive reiterative practices of our everyday lived experiences (Butler 1990). Therefore, the construal of women's agency in the film was discussed highlighting how the varied representations diffused in society impact the way we perceive ourselves and behave socially. Understanding that media representations possibly become "a form of one's social and subjective identity" (de Lauretis 1999:260), there needs to be a move beyond restrictive notions of gender roles and differences to include opportunities for the depiction of people's identities in their rich complexities and intersectional relations of gender, race, ethnicity, class, age, spirituality, body diversity and sexuality. 
Regarding the main results, almost all instances in the data concerned the non-specialized field of discourse, placing women's action mostly in the private realms of society - with the sole exception being the scarce depictions of three of the four main characters working. Second, of the actions in which women affected others, most referred to their intimate relationships with their partners (e.g. hugging, having sex, kissing) and their close relationships with their friends (e.g. drinking, eating). When their agency did not affect anyone/anything, most had to do with them just standing or walking around the city, and most strikingly with them simply smiling.

Despite the fact that we are all increasingly more "aware that 'belonging' and 'identity' are not cut in rock, that they are not secured by a lifelong guarantee, that they are eminently negotiable and revocable" (Bauman 2004:11), the visual construals in the Intro seem to create a generalized notion of women as more emotional and mostly inhabiting the private space in relationships that are limited to their partners and closest friends. Despite being a more provocative series when compared to its predecessors, especially in terms of the issues discussed on primetime TV, one could argue that SATC still seems to reiterate a performativity of womanhood rooted in regulatory practices of body weight, age, appearance and race/ethnicity.

An encouraging result, however, is that the discourse of the dynamic image in the Intro also creates some space for women to exist outside the generally restricting scope of media representations, which clearly demonstrates that power in discourse and social processes may function towards more equitable representations. For instance, in times when human bonds seem to be increasingly frailer (Bauman 2004), seeing the four main characters in enduring friendships with one another is quite significant.

Additionally, even though marriage and motherhood are given prominent attention in the Intro of the film, one of the four main characters decides to break up her relationship in search of more fulfilling personal and professional experiences. While appreciating the legitimacy of marriage, being single can also be construed as a valid choice for women in society, thus expanding the possibilities for identity work to be expressed socially. 
The film Intro also seems to present more equitable representations of motherhood, as varied configurations are depicted. While Carrie and Samantha are single with no children, Charlotte and Miranda are married with one child each, having gone through quite different experiences. While Charlotte could not conceive and decided to adopt a baby with her husband (Harry), Miranda got pregnant by accident with her boyfriend (Steve), with whom she gets married. Such different experiences portrayed contribute to making visible the many ways motherhood (and fatherhood) can be experienced in society, stressing that the perception and construal of one's gender is a matter of performativity (Butler 1990, 2004) as they are reiterated in our social and cultural exchanges, i.e. they are not instinctual.

In general terms, results indicate a placement of women's agency mostly in the private realm, with only a few depictions falling outside the socially and culturally regulatory norms. These representations are, in nuce, restricting but also enabling, making it ever more imperative to investigate and interrogate the ways in which the media may impact our beliefs and decisions, thus offering us ideas about reality. Therefore, collective actions towards more responsible and engaged participation in our everyday social practices is paramount, potentially enabling more balanced (gender) identity relations in society.

Notably, in the present study, MCDA has proved to be an approach to multimodal discourse that allowed for a discussion of how varied semiotic resources can be used to construe specific representations in the media. Such perspective is arguably applicable not only in language studies but also in other knowledge domains, such as sociology, cultural studies, feminist and media studies, since it emphasizes how meanings are created multimodally to sustain or challenge unequal power relations through discourse.

Finally, critically oriented multimodal studies also have important pedagogical implications, considering that school curricula have been increasingly directing "explicit pedagogic attention (...) to the role of images in creating evaluative stance" (Unsworth 2015:73) in multimodal texts distributed across diverse communication channels and by ever-changing technological resources. In this respect, aiming to develop students' multimodal communicative competence (Royce 2007; Heberle 2010), there needs to be a commitment to fostering educational 
practices that enable teachers to expand their own theoretical and methodological repertoires to deal with multiple semiotic resources and their interrelations in multimodal texts in the classroom. Also, the choice of multimodal texts for the classroom needs to consider a more encompassing view of which literacies can integrate the curriculum, creating a prolific link between literacies at school and elsewhere, such as films, TV shows, social networks, and blogs.

For its more comprehensive approach to the study of multiple semiotic modes, MCDA might be the spur schools needed to bridge the gap between what students study at school and their personal interests, thus enhancing the connection between formal learning and their daily lived experiences as readers and writers outside the classroom. In the context of multiliteracies, MCDA may also allow teachers and students to read texts more critically and potentially help to reconfigure unjust social structures in their lives and in the lives of those around them, contributing to the construction of more fair-minded, unbiased and prosperous collective experiences in contemporary society.

\section{Acknowledgements}

I would like to thank CNPq (National Council for Scientific and Technological Development) and CAPES (Coordination for the Improvement of Higher Education Personnel) for the financial support during my joint $\mathrm{PhD}$ studies in Brazil and in Australia, respectively. I would also like to express my deepest gratitude to my former supervisor Dr. Viviane Heberle (UFSC) for her unwavering support and mentorship in discussions about the intricate connections between (gender) identity, discourse and society. Finally, I thank my former supervisor Dr. Jim Martin (USYD) for his insightful feedback about the expanded visual social actor network proposed in this paper.

\section{References}

BALDRY, A.; THIBAULT, P. J. 2005. Multimodal transcription and text analysis: a multimedia toolkit and coursebook with associated on-line course. London/Oakville: Equinox. 
BATEMAN, J. 2009. Film and representation: making filmic meaning. In: WILDGEN, W.; HEUSDEN, B. van (Eds.). Metarepresentation, cultural evolution and art. Bern: Lang. p. 137-162.

BAUMAN, Z. 2000. Liquid modernity. Cambridge/Malden: Polity Press.

BAUMAN, Z. 2004. Identity: conversations with Benedetto Vecchi. Cambridge/Malden: Polity Press.

BENWELL, B.; STOKOE, E. 2006. Discourse and identity. Edinburgh: Edinburgh University Press.

BEZERRA, F. 2008. 'Sex and the City': an investigation of women's image in Carrie Bradshaw's discourse as narrator. Dissertação de Mestrado. Pós-graduação em Inglês. Universidade Federal de Santa Catarina, Florianópolis, SC.

BEZERRA, F. 2012. Language and image in the film 'Sex and the City': a multimodal investigation of the representation of women. Tese de doutorado. Pós-graduação em Inglês. Universidade Federal de Santa Catarina, Florianópolis, SC.

BEZERRA, F. 2016. Lendo a imagem dinâmica em uma análise multimodal da representação da mulher em Sex and the City. In: ALMEIDA, D. (Eds.). Novas perspectivas em análise visual: do texto ao contexto. Campinas: Mercado de Letras. p. 71-88.

BEZERRA, F.; NASCIMENTO, R.; HEBERLE, V. 2010. Análise multimodal de anúncios do programa 'Na Mão Certa'. Revista Letras, 20(40): 9-26.

BÖHLKE, R. de F. 2008. Constructing ideal body appearance for women: a multimodal analysis of a TV advertisement. Tese de Doutorado. Pós-graduação em Inglês. Universidade Federal de Santa Catarina, Florianópolis, SC.

BOUVIER, G. 2018. Clothing and meaning making: a multimodal approach to women's abayas. Visual Communication, 17(2): 187-207.

BUBEL, C. 2006. The linguistic construction of character relations in TV drama: doing friendship in Sex and the City. Unpublished PhD dissertation. Faculty of Philosophy, Saarland University, Germany.

BUTLER, J. 1990. Gender trouble: feminism and the subversion of identity. London/New York: Routledge.

BUTLER, J. 2004. Undoing gender. New York: Routledge.

CHEN, A.; MACHIN, D. 2014. The local and the global in the visual design of a Chinese women's lifestyle magazine: a multimodal critical discourse approach. Visual Communication, 13(3): 287-301.

De LAURETIS, T. 1999. Gender symptoms, or, peeing like a man. Social Semiotics, 9(2): 257-270. 
Di MATTIA, J. 2004. 'What's the harm in believing?': Mr Big, Mr Perfect and the romantic quest for Sex and the City's Mr Right. In: AKASS, K; MCCABE, J. (Eds.). Reading Sex and the City. London: I.B. Tauris. p. 17-32.

DJONOV, E.; ZHAO S. (Eds.). 2014. Critical multimodal studies of popular discourse. New York: Routledge.

GALASINKSI, D. 2004. Men and the language of emotion. New York: Palgrave Macmillan.

HALLIDAY, M.A.K. 1978. Language as a social semiotic: the social interpretation of language and meaning. London: Edward Arnold.

HALLIDAY, M.A.K.; MATTHIESSEN, C. M. I. M. 2004. An introduction to functional grammar. 3. ed. London: Edward Arnold.

HEBERLE, V. 2010. Multimodal literacy for teenage EFL students. Cadernos de Letras UFRJ, 27: 101-116.

IEDEMA, R. 2001. Analysing film and television: a social semiotic account of Hospital: an Unhealthy business. In: VAN LEEUWEN, T.; JEWITT, C. (Eds.). Handbook of visual analysis. London: Sage. p. 183-204.

KERRY, V. 2016. The construction of hegemonic masculinity in the Semiotic Landscape of a CrossFit 'Cave'. Visual Communication, 16(2): 209-237.

KRESS, G.; van LEEUWEN, T. 2006. Reading images: the grammar of visual design. 2. ed. London/New York: Routledge.

LEDIN, P.; MACHIN, D. 2018. Multi-modal critical discourse analysis. In: FLOWERDEW, J.; RICHARDSON, J. (Eds.). The Routledge handbook of critical discourse studies. London/New York: Routledge. p. 60-76.

LIMA-LOPES, R. 2016. Vídeos publicitários e o discurso da tecnologia: metáforas verbo-visuais. D.E.L.T.A., 32(2): 325-354.

MACHIN, D. 2016. The need for a social and affordance-driven multimodal critical discourse studies. Discourse \& Society, 27(3): 322-334.

MACHIN, D.; CALDAS-COULTHARD, C.; MILANI, T. 2016. Doing critical multimodality in research on gender, language and discourse. Gender and Language, 10(3): 301-308.

MARTIN, J. R. 1992. English text: systems and structure. Philadelphia/ Amsterdam: John Benjamins Publishing Company.

MISHRA, S. 2017. From self-control to self-improvement: evolving messages and persuasion techniques of weight loss advertising (1930-1940). Visual Communication, 16(4): 467-494.

MONTEMURRO, B. 2004. Charlotte chooses her choice: liberal feminism on Sex and the City. The Scholar \& Feminist Online, 3(1): 1-3. 
OECD. 2017. Obesity update. OECD obesity update 2017. Retrieved from: <http://www.oecd.org/health/obesity-update.htm>. Access: September 5, 2018.

O'HALLORAN, K. L. 2004. Visual semiosis in film. In: O'HALLORAN, K. (Ed.). Multimodal discourse analysis: systemic functional perspectives. London/New York: Continuum. p. 109-130.

PIAZZA, R.; BEDNAREK, M.; ROSSI, F. (Eds.). 2011. Telecinematic discourse: approaches to the language of films and television series. Amsterdam: John Benjamins.

PIMENTA, S.; NATIVIDADE, C. 2012. Humano, demasiadamente humano: sobre emoções e masculinidade. D.E.L.T.A., 28(Especial): 605-637.

RODERICK, I. 2016. Representing affective labour and gender performativity in knowledge work: a multimodal critical discourse analysis. Gender and Language, 10(3): 386-411.

ROYCE, T. 2007. Multimodal communicative competence in second language contexts. In: __ ; BOWCHER, W. (Eds.). New directions in the analysis of multimodal discourse. Mahwah/NJ: Lawrence Erlbaum. p. 361-403.

SUNDERLAND, J.; McGLASHAN, M. 2013. Looking at picturebook covers multimodally: the case of two-Mum and two-Dad picturebooks. Visual Communication, 12(4): 473-496.

TSENG, C. 2009. Cohesion in film and the construction of filmic thematic configuration: a functional perspective. Unpublished $\mathrm{PhD}$ thesis. Faculty of Linguistics and Literary Sciences, University of Bremen, Germany.

USDL - United States Department of State. 2016. News Release. Bureau of Labor Statistics. Retrieved: <https://www.bls.gov/news.release/ archives/atus_06242016.pdf>. Access: September 6, 2018.

van LEEUWEN, T. 1996. Moving English: the visual language of film. In: GOODMAN, S.; GRADDOL, D. (Eds.). Redesigning English: new texts, new identities. London: Routledge. New York: Open University. p. 81-105.

van LEEUWEN, T. 2008. Discourse and practice: new tools for critical discourse analysis. Oxford/New York: Oxford University Press.

Recebido em: 30/05/2019

Aprovado em: 28/05/2020 